\title{
UNDERSTANDING SUPPLY CHAIN MANAGEMENT CONCEPTS IN THE CONTEXT OF PORT LOGISTICS: AN EXPLANATORY FRAMEWORK
}

\author{
Nico Herz, Heike Flämig \\ Institute for Transport Planning and Logistics, Hamburg University of Technology, Hamburg, Germany
}

Submitted 19 April 2013; resubmitted 19 October 2013; accepted 14 March 2014

\begin{abstract}
In academia as in practice, seaports are increasingly viewed as elements in supply chains. It is argued that seaports should add value to shippers by aligning their own business activities with shippers' Supply Chain Management (SCM) strategies and requirements. The implications of this 'port-SCM' philosophy are not fully explored, however. In this context, it is especially important to create mutual understanding between shippers, in terms of their SCM strategies, and port actors, in terms of services provided. In this paper a framework is developed, which aims to improve mutual understanding between shippers and port actors from a SCM point of view. It thereby aims to contribute to the dialogue on how the port logistics system can be better integrated into shippers' SCM strategies. Three SCM reference models are analysed and twelve SCM subsystems identified that represent broad design areas of shippers' SCM strategies. Further, the seaport system is discussed in terms of system boundaries and the actors involved. Port actors and SCM subsystems are then combined into one explanatory framework, the SCM-port actor matrix. Finally, applying the matrix, three cases retrieved from academic and trade literature in which port actors are actively involved in conducting shippers' supply chain strategies are discussed. The paper concludes with a brief outlook on future research needs.
\end{abstract}

Keywords: port actors; supply chain management; SCM subsystems; SCM-port actor framework; logistics.

\section{Introduction}

Principles of Supply Chain Management (SCM) have become increasingly present in research on seaports (Robinson 2002; Carbone, De Martino 2003a; Bichou, Gray 2004; Van der Lugt, De Langen 2005; Beresford et al. 2011). In his seminal article 'Ports as elements in value-driven chain systems' Robinson (2002) describes the need for ports to be understood not just as places for ship and cargo handling but as elements in valuedriven chain systems. It is not, therefore, individual ports that compete with each other, but chain systems in which ports are embedded (Robinson 2002). Ports, in this context, should add value for port customers and their supply chains. This notion addresses one of the key principles in SCM: the orientation of business activities to customer requirements (Mentzer et al. 2001).

In the port context, Carbone and De Martino (2003a) identify an extension of a port's traditional customer base: requirements of shippers become increasingly important (Carbone, De Martino 2003a), putting ports under pressure to develop capabilities such as external coordination and exercising control over the entire supply chain. In this thinking, the port both serves as an integral part of the transport system and represents a subsystem of the larger production and logistics system (Bichou, Gray 2004). However, although practical cases of supply chain involvement of ports emerge, critical voices note that implications of a supply chain focus for ports have yet to be fully explored (Heaver et al. 2000).

Drawing on Robinson (2002), Mentzer et al. (2001), Carbone and De Martino (2003a) and others, this paper builds on the observation, that SCM strategies of shippers can have an impact on the logistics strategies and the business requirements of port actors. When port actors understand which services shippers require in view of their SCM strategies, and, vice versa, shippers understand which services port actors provide, both can potentially gain or maintain a competitive advantage. It is, however, not always apparent from a port actor viewpoint what characterises the SCM strategies of a shipper, nor is it always clear which services port actors provide from the view point of shippers' Supply Chain (SC) strategies.

In this paper, therefore, a conceptual explanatory framework is developed, the SCM-port actor matrix, which helps to increase mutual understanding by combining shippers' SCM subsystems with the port actors'

Corresponding author: Nico Herz

E-mail: nico.herz@tuhh.de 
activities. The subsystems represent broad design areas of shippers' SCM strategies. By combining them with various port actors in a matrix structure, different aspects of port SC involvement can be explored:

- the matrix serves as a research tool that can be used to map relations between port actors and shippers' SCM strategies;

- this framework is also applicable to port business practice in the sense that it can support port actors in understanding shippers' SC strategies and requirements;

- it can further be utilised to improve shippers' efforts to strategically analyse the port and shipping market when building maritime transport chains.

Furthermore, this paper identifies and addresses content-related as well as methodological shortcomings of the 'port-SCM' domain. In particular, the framework developed helps to bridge the gap between the theoretical concept of SCM and implications for port logistics practice. The paper also uses a more far-reaching definition of SCM compared to other papers in the port-SCM research arena. Finally, the clear distinction of different groups of port actors and shippers represents a reminder to the per se well established fact that a 'port' is actually a heterogeneous construct of actors, processes and functions.

The following approach has been chosen: First, different SCM reference models are explored and general SCM subsystems are derived. Then the seaport system is analysed in terms of its system boundaries and the actors involved. Port actors and SCM subsystems are then combined into an explanatory framework, the SCM-port actor matrix. Using selected practical examples, the applicability of the matrix approach is discussed. The paper concludes with initial insights into how port actors can be systematically included in shippers' SCM strategies and a brief outlook for future research.

\section{1. 'Ports in SCM': the Current State of Research}

In the introduction, seaports were described as elements in SCs that should increasingly align their business along shippers' requirements. In the following the question answered is why, in fact, the port system deserves a specific consideration in research on SCM. Marlow and Paixão Casaca (2003) state that the demand for port services is 'double-derived', driven by the demand for transport/ shipping services which in turn depends on the demand for goods. To remain competitive, ports thus need to follow shipper-driven logistics practices (Marlow, Paixão Casaca 2003). It has been widely described that shippers' SC practices have undergone ample change in the last decades. SCs became more complex, global, and longer (Beresford et al. 2011). Transport and logistics operators as well as port actors were forced to adapt accordingly, integrating vertically and horizontally, increasing the range of services provided as well as its geographic coverage of conditions of higher service quality and lower prices per unit along the entire SC (Heaver 2002; Slack et al. 1996; Beresford et al. 2011). Seaports thereby represent critical nodes in maritime SCs. The reasons include, for example, their role as interfaces between sea and land-based transport modes, the multitude of logistics services provided or the trade function for the port region. For shippers, seaports therefore provide opportunities to 'tune' their SC operations. However, they potentially can also pose threats to shippers' SCs when for example SC disruptions occur, such as the 2002 US West coast port lockout (Hall 2004). In any case, whether threat or opportunity, seaports today are critical elements in shippers' SCs and their management.

The port and logistics research community discovered the topic 'ports in transport and SCs' at the beginning of the 21st century. Following Robinson's well received article (Robinson 2002), research in the portSCM domain included work on the integration potential of port operators in car manufacturing SCs (Carbone, De Martino 2003a), new approaches to port performance measurement integrating SC indicators (Marlow, Paixão Casaca 2003; Bichou, Gray 2004), insights on terminal SC integration (Panayides, Song 2009) as well as the development of port-centric logistics concepts (Beresford et al. 2011; Mangan 2009; Wall 2007). Given the relative novelty of the research field, authors identify shortcomings, both, thematic/content-related and methodological/conceptual.

The most wide-reaching content-related critique points towards the difficulty of establishing content reference between the theoretical concept of SCM and the practical implications for seaports as SC elements. Panayides (2006) in this context state that 'although a lot has been written on the importance of integration across the SC (between liner companies, port operators, logistics providers, suppliers, etc.) little has been offered in terms of conceptualization and empirical evidence of what really is meant by 'integration in the supply chain' [...]'. Similarly, Robinson (2002) calls for new concepts and frameworks that help to understand the role of ports in a complex, SC driven business environment. On the other hand, the SC discussion in ports is not purely academic, but increasingly has practical implications and cases. SC initiatives or concepts can for example be found at Port Metro Vancouver (Heaver 2011), the Port of Antwerp (Port of Antwerpen 2010) or the Ports of Dubai (Jacobs, Hall 2007). Another well documented example is the port-centric logistics initiatives of various British Ports (Mangan et al. 2008). In many instances however, a general lack of knowledge about SCM approaches in port logistics is prevalent within the port community (Bichou, Gray 2004). In summary, it cannot yet be anticipated to what end the 'port in SCs' discussion will lead. Heaver et al. (2000) in this context state that for now the ultimate outcome of stronger integration in port and maritime industries remains unclear for ports and port authorities.

Conceptual and methodological shortcomings of SCM-related port research can be identified in two main areas. First, many authors avoid giving a clear definition of the term 'port' or 'seaport' in the context of their work, ignoring the fact that ports are in fact complex en- 
tities (Robinson 2002) with numerous actors and myriads of processes. Hence, system boundaries with respect to the object of research are often vague, making it, for example, difficult to transfer research results into practice or to specific port actors or processes. Second, with very few exceptions, papers neither discuss models from SCM theory in detail nor do they apply concrete models to the port environment (for an exception see Carbone and De Martino (2003a)) but, if at all, only fragments or a simplistic idea of the broader SCM concept.

\section{Review of SCM Reference Models}

The term SCM has risen to prominence both in business and in academia. A widely accepted definition is provided by the Council of Supply Chain Management Professionals (CSCMP 2012): 'supply chain management encompasses the planning and management of all activities involved in sourcing and procurement, conversion, and all logistics management activities. Importantly, it also includes coordination and collaboration with channel partners, which can be suppliers, intermediaries, third party service providers, and customers. In essence, SCM integrates supply and demand management within and across companies'. Talley (2009), arguing similarly, extends SCM activities to warehousing, transportation as well as port and other terminal operations.

Authors have developed reference models/conceptual frameworks of SCM to further structure, explain and substantiate the concept of SCM. Reference models represent a conceptual frame, i.e. they have a superior, higher-level character and form the foundation for more specific models/approaches. They do not refer to specific cases but constitute problem-spanning models and are therefore comprehensive, more generic and abstract in nature (Corsten, Gössinger 2007; Stahlknecht, Hasenkamp 2004). Reference models aim to standardise processes across companies and industries and make an important contribution in terms of providing transparency, guidance and the ability to communicate for analysing and optimising SCs (Hertel et al. 2011; Corsten, Gössinger 2007). Three SCM reference models have been chosen for analysis in the context of this paper, the Supply Chain Operations Reference (SCOR) model, the SC integrative framework of Bowersox et al. (2007), and the conceptual framework of SCM (Cooper et al. 1997). A detailed presentation of the three models would go beyond the scope of this paper, however. So the focus is on those parts of the models that provide the best answer to the question what constitutes SCM.

\subsection{SC Operations Reference Model}

The SCOR model, developed by the Supply Chain Council (SCC), has been included because of its high practical relevance and its broad application in practice. It represents a quasi-idealistic model of a SC, designed as a holistic, standardised SC reference model with applicability across companies and industries aiming to describe, analyse and assess SCs in a unified manner (Poluha 2010). It is organised in a three-level structure.
On Levels 1 and 2 the SC architecture is described. Level 3 specifies best practices in executing Level 2 processes (Zhou et al. 2011; SCC 2010). Two additional levels include industry- and organisation-specific steps. In the context of this paper only Level 1 management processes - 'Plan' (planning activities related to SC operations), 'Source' (activities related to ordering up to the receipt of goods and services), 'Make' (transformation of materials and generation of services), 'Deliver' (creation, maintenance, and fulfilment of customer orders), and 'Return' (reverse flows from the customer to the supplier) (Zhou et al. 2011) - are of relevance for deriving general SCM subsystems. This is because it is the interaction of those five integrated SC processes across SC members, from the suppliers' supplier to the customers' customer, that characterises SCM in the context of SCOR (Bolstorff, Rosenbaum 2007). It builds the uppermost level of the model and comes closest to answering the question of what constitutes SCM. With respect to the focus of this paper, it must be stressed that transportation and warehousing are integral parts of the SCOR model as elements of subordinate levels.

\subsection{SC Integrative Framework of Bowersox et al. (2007)}

The SC integrative framework of Bowersox et al. (2007) has been included due to its comprehensiveness and its all-embracing assumptions, making it a good starting point for empirical investigation (Horch 2009). It aims to identify the nature, i.e. the range and continuity, of collaboration in SCs required to achieve effective and efficient SC flows (Bowersox et al. 2007). Four different SC flows form the basis of the framework: the product/service value flow, the (reverse) market accommodation flow, information flow and cash flows (for detailed information see Bowersox et al. (2007)). To increase effectiveness and efficiency of those SC flows, Bowersox et al. (2002) identify six relevant SC competencies: customer integration, internal integration, supplier integration, technology and planning integration, measurement integration and relationship integration, which, if implemented and integrated between SC members, could eventually help to reduce delay, redundancy and inefficiency in the SC (Bowersox et al. 2002). Customer integration builds on operating ties with downstream SC partners, supplier integration with upstream SC partners (Bowersox et al. 1999, 2002). Internal integration deals with the coordination of intrafirm functions related to procurement, manufacturing, and distribution (Bowersox et al. 1999). Technology and planning integration is the competency of providing information systems that fulfil requirements of multitude operational arrangements and market segments (Bowersox et al. 1999). Measurement integration aims to realise intra- and inter-firm/SC performance monitoring and benchmarking (Bowersox et al. 1999). Relationship integration deals with the management of business relationships between SC partners (Bowersox et al. 2002). 


\subsection{Conceptual Framework of SCM Based on Cooper et al. (1997)}

The conceptual framework of Cooper et al. (1997) was included because of its broad scope, its inter-organisational focus, and its strong process orientation (Horch 2009; Heusler 2004). The framework includes three basic interconnected elements: the SC network structure dealing with the overall configuration of the SC (Cooper et al. 1997), business processes, defined as intra- and inter-organisational activities that generate value to the customer, and management components that support and provide structure to business processes across SC companies (Cooper et al. 1997). In the following the focus is on the eight business processes as it is their integration across the SC that represents SCM in the model context (Cooper et al. 1997). Business processes are customer relationship management (strategic development of customer relationships), customer service management (operational customer interface), demand management (synchronises customer requirements with a firm's supply capacity), order fulfilment (generating and servicing customer orders), manufacturing flow management (product flow throughout manufacturing process), supplier relationship management (strategic development of supplier relationships), product development and commercialisation (integration of customers and suppliers into the product development process) and returns management (reverse product flows from the customer to the supplier) (Croxton et al. 2001; Lambert 2008; Lambert, Cooper 2000).

\section{Subsystems of SCM}

In the following the three reference models are compared and general SCM subsystems are derived as input factors for the later developed SCM-port actor matrix.

\subsection{Research Approach and Methodology}

For the following analysis it is important to understand that this is not an attempt to integrate the reference models which would go beyond the scope of this paper and is not expedient with regard to what the deeper understanding of the SCM concept here is needed for. This paper therefore refrains from pursuing a meta-level analysis of the reference models as for example performed by Burgess et al. (2006), Soni and Kodali (2013) or Lambert et al. (2005) and does not aim to develop what Giannakis and Croom (2004) call a cognate SCM discipline. Its intent is to create a comprehensible, yet detailed and comprehensive, picture of SCM and to apply it to a comparatively new domain, the port environment.

The analysis will therefore be conducted by an inductive process that compares the various elements of the models, tries to identify commonalities and group those elements where there is substantial overlap. Those groups are called 'SCM subsystems' and represent broad design areas of shippers' SCM strategies.
As explained before, the five Level 1 management processes of the SCOR model (plan, source, make, deliver and return), the six SC competencies and three context levels of Bowersox et al. (2007) and the eight SC business processes of Cooper et al. (1997) are used as input to the analysis and the building of subsystems as they describe best what constitutes SCM in the context of each of the models.

It is unequivocally clear that the building of groups is exposed to the risk of a certain degree of methodological flaw, as each of the models represent an individual explanatory approach towards SCM and highlights different aspects of the broader concept. To keep these inconsistencies to a minimum, we therefore use the SCM definition of the Council of Supply Chain Management Professionals (CSCMP 2012) presented earlier in this work to further structure the subsystems identified into four layers:

- the superordinate layer, which encompasses all general management activities;

- the relationship layer, which includes all coordination and collaboration activities with upstream and downstream SC partners;

- the value adding layer, which encompasses all product and service related transformation processes;

- the logistics layer, which comprises physical transport, handling and storage activities.

Given the nature and intent of this paper, we think that this approach is viable.

\subsection{Identification of SCM Subsystems}

In total, twelve subsystems have been identified in the process of clustering and have been assigned to the four SCM layers. Explanations of the subsystems will follow the structure of Fig. 1 from top to bottom.

The superordinate layer consists of the subsystems plan (1) and measure (2). Plan activities are included in the SCOR model ('Plan') as well as in the model of Bowersox et al. (2007) ('Technology and Planning Integration'). Whereas Bowersox et al. (2007) explicitly stress the importance of information in planning, SCOR applies a more general definition of planning with the matching of supply and demand in the SC. Measure is named as an explicit competency in the reference model of Bowersox et al. (2007) ('Measurement Integration'), being performance monitoring and benchmarking within and across SC members. It is also an important element in the SCOR model, not, however, as a key process but as an individual SCOR performance segment that distinguishes between performance attributes and metrics (Poluha 2007; SCC 2010).

The relationship layer encompasses three subsystems. Supplier relationship management (3) represents a business process within the model of Cooper et al. (1997). In the same context Bowersox et al. (2007) identify supplier integration as an important SC competency. Furthermore, suppliers as well as suppliers' suppliers are included in the SCM definition of the SCOR model. 


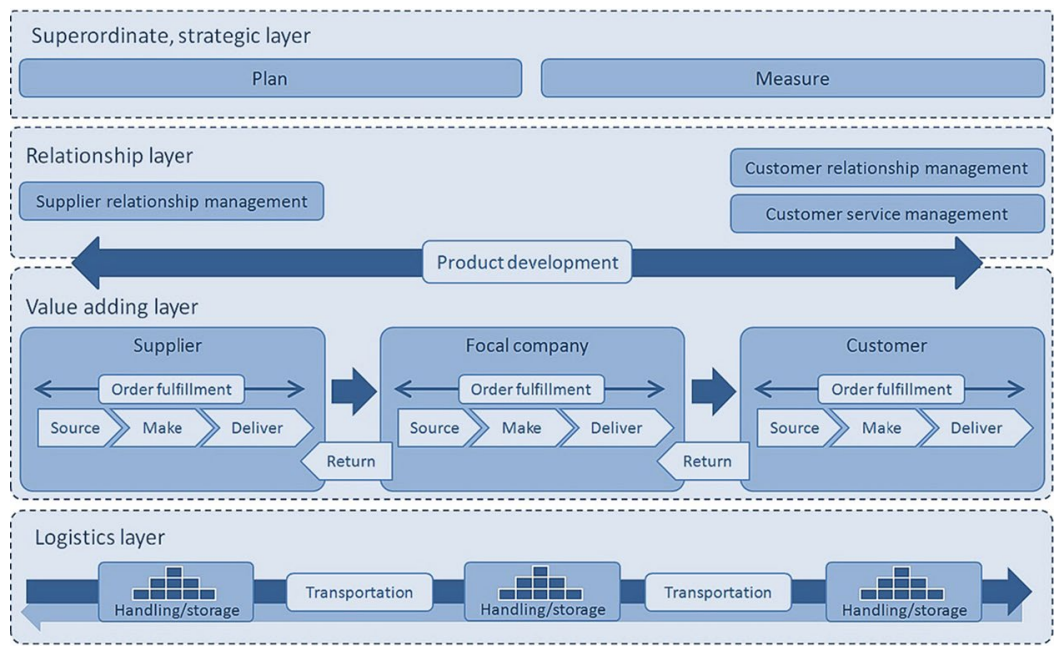

Fig. 1. Subsystems of SCM (compiled by the authors)

The management of relationships with customers is also part of the models analysed. Cooper et al. (1997) distinguish between the largely strategic customer relationship management (4) and the more operational customer service management (5). Bowersox et al. (2007) view customer integration as another SC competency whereas SCOR includes the customer and the customer's customer as major downstream players in SCM.

The value-adding layer includes all elements that are directly linked to product or service-related transformation processes across SC members. Sourcing (6) processes can be found in the SCOR model as one of the basic SCOR processes and in Cooper et al. (1997) as demand management that aims to balance customer demands with a firm's supply capacity. Make (7) processes logically follow sourcing activities and deal with all product-related value adding activities throughout the manufacturing process. The respective processes are outlined in SCOR ('Make') as well as in Cooper et al. ('Manufacturing Flow Management'). Deliver (8) as a single element was named only in the SCOR model. It is, however, also included in Cooper et al. (1997) as part of business process order fulfilment, implying that overlap of content exists between the two elements. All activities related to and accompanying the customer order can be subsumed under order fulfilment (9), included in the reference model of Cooper et al. (1997). Return (10) in terms of reverse flows from the customer to the supplier can be found in the SCOR model ('Return') as well as in the conceptual framework of SCM of Cooper et al. (1997) ('Returns Management'). A strong interconnection with the make process can thus be observed, especially within the SCOR model, as sub-processes such as repair, overhaul, and recycling are located here. Product development (11), part of the model of Cooper et al. (1997), includes suppliers and customers in the process of bringing products to market. It is therefore placed at the interface between the relationship layer and the value adding layer.

The logistics layer subsumes physical storage, handling, and transportation activities (12). These processes can be found on or between each level of the SC. As a prerequisite for physical SC flows, they do not represent individual elements in the models but are assigned as sub-elements, for example in the deliver process (transport) and the source process (storage) of the SCOR model.

\section{The Port Actor Landscape}

To apply the SCM subsystem framework to port-related SCM activities it is necessary to develop an understanding of what constitutes a seaport system and which actors belong to it. These questions are a matter of academic dispute, as seaports are heterogeneous entities in many aspects such as assets, roles, functions or institutional organisation. At the extremes a seaport is something between a small quay for berthing and a large-scale centre with various terminals, industries and services (Bichou, Gray 2005a). Notteboom (2006) emphasise the SC/network function of a port which '[...] plays an active role in the global transport system and is characterised by a spatial and functional clustering of activities that are directly and indirectly involved in transformation and information processes in supply chains' (Notteboom 2006). Carbone and De Martino (2003a) stress that ports can be understood ' $[. .$.$] as a cluster of organizations in$ which different logistics and transport operators are involved [...]'. Talley (2009) divides port actors into port users, who demand port services and port service providers, who supply the services needed. The first group encompasses sea- and land-based carriers as well as shippers and passengers. Service providers include port operators such as port authorities, terminal operators or terminal operating shipping lines as well as stevedores, ship agents, pilotage and towage, ship repair and maintenance, customs brokers, freight forwarders, third-party logistics companies, including value-added services and warehousing, governmental and regulatory bodies (Talley 2009).

From an academic standpoint the decision on which actors to include in an analysis and if (and how) 
to group them ultimately depends on the characteristics of the research undertaking. This paper explores interaction between two groups of organisations: shippers (and their SCM strategies) and actors/service providers of the port logistics chain also called 'port actors' throughout this paper. The latter may potentially include all actors in the maritime transport chain, as they either operate within the port complex directly or maintain geographic or functional interfaces with it (Herz et al. 2013). However, to keep it simple, it makes sense to proceed with a condensed actor landscape in order to not add further complexity, as in the following the focus is on discussing/testing the general applicability of the framework developed rather than on generating large-scale empirical results. This approach still provides a reasonable level of detail compared to other publications in the research field. The port actor categories used in the following are forwarders and Logistics Service Providers (LSP), shipping lines, port authorities, port/terminal operators as well as warehousing and value added services providers. It follows in large parts other authors in the research field such as Bichou and Gray (2005b) or Heaver (2011). The approach can however be easily extended or broken down into a more detailed version.

Further terminological confusion that needs to be addressed exists due to the fact that comparably to the term 'port actor' the term 'shipper' is used in a contextdependent manner. Talley (2009) defines shippers as 'business firms or persons that utilise carriers for the transportation of goods from origin to destination locations'. This is often equated with '[...] the owner of goods being transported' (ESC 2013). However, a shipper can also be a shippers' association or an ocean transportation intermediary/non-vessel operating common carrier (Stumm 2010). For the purpose of simplification, in the following a shipper is understood as a buyer or seller of a product that needs to be transported.

\section{SCM-Port Actor Framework: Examples from Business Practice}

Identified SCM subsystems and actors of the port system are combined into an SCM-port actor matrix. SCM subsystems are used as row headers and represent broad areas of shippers' SCM strategies. Port actors are used as column headers. They represent the players who are active in a shipper's SC. From a research perspective, by filling in the matrix, different aspects of the interplay between shippers and port actors can be explored. Fields of the matrix can be used to map activities of different port actors within the various SCM subsystems of a shipper. From a shipper's perspective, a completed matrix helps to understand which strategic role port actors play in view of its SCM strategies. From a port actor's perspective a completed matrix can be used to identify its role vis-à-vis its customer (the shipper). In the two later cases, this information can be utilized as a supportive management tool for decision making in logistics chain building and service provision.

Some conceptual implications need to be considered when using the matrix. As shippers' strategies are idiosyncratic, the specific elaboration of the subsystems will differ from shipper to shipper. Some subsystems may not have to be considered at all, for example a trading company is unlikely to pursue any 'make' processes. Furthermore, the same is true when matching the subsystems with port actors' activities. It goes without questioning that each seaport represents an individual set of involved companies and services. How port logistics services fit specific SC requirements of shippers thus depends on the case considered. Ultimately, ports (and port actors) will play different roles in different SCs (Beresford et al. 2011). Depending on the port and port actor respectively, some fields of the matrix will remain empty because no services are provided that match a specific SCM subsystem. The subsystems only provide a 'frame' in which port actor services can be discussed as elements of shippers' SCM strategies. The actual elaboration of the matrix is port (actor) as well as shipper specific, i.e. it depends, first on which SCM subsystems are important in a specific port actor-shipper relationship, second, on which port actors are involved and third, on how the actual relationship is shaped (i.e. what goes into the matrix).

In the following, using the matrix (i.e. filling in its fields) three cases retrieved from academic and trade literature in which port actors are actively involved in conducting shippers' SC strategies are discussed (see Fig. 2, in which examples are numbered consecutively according to their appearance in this paper).

\subsection{ASDA}

A prominent example of cooperation between a retailer and a port operator is the case of ASDA (ASquith DAiries), a large British food retailer. ASDA operates between the poles of long lead times for sourcing goods from Asia and rather short-term changes in retail customer demand patterns (Analytiqa 2007). Especially ASDA's distribution centres and stores in the north of the UK suffered from delays and SC disruptions in southern UK ports, where $90 \%$ of ASDA's cargo came through, and from congestion in the UK road network (ASDA 2012). Increasing flexibility and responsiveness as well as lead-time reductions therefore represent key elements in ASDA's SC strategy. In the language of the SCM subsystem framework sourcing, delivery, warehousing and distribution activities as well as customer service represent key fields of activity for ASDA. As a response towards described challenges, ASDA, together with the port operator PD Ports, built an import centre in the direct vicinity of the container terminal of the northern UK seaport Teesport. Furthermore, to supply the import centre, a coastal feeder service connection between the ports of Felixstowe and Teesport was established to reroute cargo further north (PD Ports 2010). The combination of a 'port-centric' import centre and feeder service enabled ASDA to (see Analytiqa 2007; PD Ports 2010; ASDA 2012):

- move stock in and out of the import centre within 24 hours to quickly respond to consumer needs; 


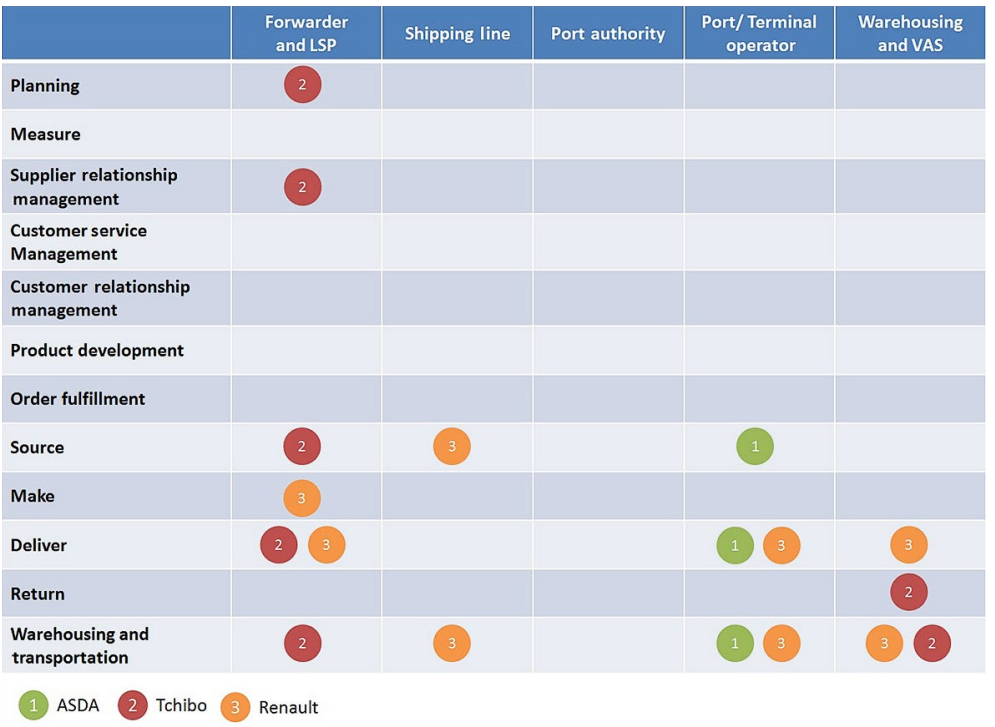

Fig. 2. Port actor-SCM subsystems matrix (compiled by the authors)

- proactively manage the distribution SC with improved visibility;

- be in close proximity to northern-based final consumers;

- avoid weather-related vulnerabilities and SC disruptions of southern British ports;

- benefit from value added services such as rework and cross-docking localities;

- save around 1.5 million road miles per annum (2009) by using the feeder service instead of trucks from southern UK ports.

\subsection{Tchibo}

Tchibo is a Germany-based, internationally operating consumer goods and retail company as well as the market leader for roasted coffee in Germany, Poland, Austria and the Czech Republic (Maxingvest AG 2012). In its non-food segment, Tchibo operates a business model with a weekly changing range of products that requires the ability to move stock in and out of warehouses, distribution centres and points-of-sale quickly. Important SC requirements are thus high product availability, efficient returns management as well as transparency of and the ability to directly influence SC processes and partners (Herz, Flämig 2012). Tchibo collaborates closely with different actors along the maritime and port logistics chain to meet these requirements. Two logistics service providers are of specific importance: a booking agent facilitating SC operations in and around the ports of origins in the sourcing countries in South-East Asia and a $3 \mathrm{PL} /$ warehouse operator at the German ports of destination Hamburg and Bremerhaven. In the sourcing countries, the booking agent plays a central role in coordinating suppliers, quality inspection centres, local drayage, terminal operators and shipping lines. Services provided by the booking agent include especially supplier communication and planning/administrative processes such as receiving, prioritising and processing bookings, ship choice, reservation of ship capacities, as well as booking execution. The booking agent thereby ensures visibility/transparency for Tchibo on its sourcing processes in overseas sourcing countries (information broker). In the logic of the SCM-port actor matrix, the booking agent supports Tchibo in terms of supplier relationship management, planning processes and transportation. A German logistics service provider is responsible for container transportation from the seaport terminals (Bremerhaven and Hamburg) to the warehouse, all warehouse operations, and value added service such as pick and pack, labelling, or product supplements. The bonded warehouse is operated as a dedicated facility for Tchibo, the two companies enjoy a long-term, close and direct relationship. The warehouse is situated on the River Weser $80 \mathrm{~km}$ upstream from the seaport of Bremerhaven and has a direct access to the container terminal Neustädter Hafen as well as a rail spur (BLG Logistics 2011). Containers arrive by barge from Bremen or by rail from Hamburg. Inbound road transportation is only used in exceptional cases. The central warehouse fuels Tchibo's complex multi-channel distribution system (around 1200 own shops in Central Europe, 29000 supermarket/store outlets as well as an online and mail order system) with goods (Maxingvest AG 2012). By the same token, at the end of product cycles, return flows are passed back through the distribution network to the central warehouse (Herz, Flämig 2012).

\subsection{Renault}

Carbone and De Martino (2003a) explore the collaboration between the car manufacturer Renault and various actors at and around the port of Le Havre. Renault engages in a sophisticated network of relationships with port and logistics actors depending on the underlying requirements of the business process considered.

In procurement, i.e. the supply of Renault plants with parts and components, low freight rates and low 
transit times are important. Procurement is predominantly managed in-house. Here, activities are vertically integrated within the Renault corporation. Only maritime port-to-port transport is performed by shipping lines on a spot contract basis. Low freight rates here are especially realised because of Renault's bargaining power. Reliability of low carrier transit times is monitored by regular quality evaluations (Carbone, De Martino 2003b).

Requirements with regard to inventory management differ for components/parts and finished vehicles. To account for those differences, Renault employs different logistics companies for service provision, one for each type of product. Both organise a network of auxiliary transport companies.

For component inventory management, logistics costs and reliability are important. For this service, Renault uses the Grand Couronne logistics platform, which is situated on the River Seine around $120 \mathrm{~km}$ upstream from Le Havre. On the logistics platform, parts of different suppliers are consolidated and car component kits (Completely-Knocked-Down-CKD) are compiled as well as larger lot sizes of individual parts. Grand Couronne then organises the transport to Renault assembly plants including transport to the port of Le Havre and performs container stuffing. Furthermore, the platform manages information flows between suppliers, Renault assembly plants and the port of Le Havre (Carbone, De Martino 2003b).

Finished cars inventory management is influenced by transit time considerations and security issues of consignments to achieve just-in-time delivery. Services are provided by CAT (Cie d'Affrètement et de Transport), a vehicle logistics service provider owned by a consortium consisting of a vehicle transportation specialist, a 3PL and an ocean carrier. CAT's subsidiary SETH, a terminal operator for cars is responsible for storage at the port of Le Havre.

Physical distribution of finished cars is driven by the need to achieve low transport costs and information transparency due to just-in-time delivery to car dealers. Requirements are met by services managed by CAT and executed by car carrier HUAL-CETAM (Carbone, De Martino 2003b).

\section{Conclusions}

This paper represents work in the comparably young domain of research on seaports and its actors in a SCM context. It builds on the observation that demand for port services is double-derived and ultimately depends on the SC needs of the ports' final customer, the shippers. Shippers increasingly act globally, which poses new challenges to their SCs such as increased complexity, security issues, risks of major disruptions and the like but also creates new business opportunities such as access to new markets, cost advantages etc. SC and transport services in this context often need to be agile and reliable and, at the same time, offered at minimum costs. Seaports as critical nodes in global SCs represent places where international transport chains merge and split and, for the most part, a large variety of logistics services is offered and pursued. For shippers, the seaport system with its actors and services can thus represent a potential threat as well as an opportunity with regard to their SC operations. In any case, whether for better or for worse, seaports today are decisive factors in many shippers' SC strategies. For a good 'fit' between shippers' SC requirements and services provided by port actors, a mutual understanding of activities, strategies and services is imperative. This, however, cannot always be taken for granted.

In this paper, a framework is developed which can help to close the knowledge gap between shippers' SCM activities and the services provided by port actors.

The comparison of the three reference models revealed that, although each of the models represent an individual explanatory approach towards SCM, with its own raison dêtre, they use in many cases comparable ideas, concepts and terminology. In total, twelve SCM subsystems have been identified, which represent broad design areas of shippers' SCM strategies. With regard to the analysis of actors involved in the seaport system, it can be concluded that ports are heterogeneous entities in many aspects such as functions, processes and actors involved. This has important implications for research in the context of shipper-port actor relationships as business cases and research findings are, in fact, port-specific. Furthermore, cases of SCM-port actor collaboration are obviously also shipper-specific. Additional specificity then also arises from the actual configuration of the relationship, i.e. the question on how a relationship is finally governed.

The framework developed allows for modelling these specificities in different ways. First, shipperspecificity can be modelled by inclusion or exclusion of different SCM subsystems depending on the overall SC strategy of the shipper considered. Shipper-specificity can further be modelled by including or excluding specific groups of port actors depending for example on the shippers' SC design. The latter also represents an approach to model port-specificity, as not all ports offer the same portfolio of services and providers. The peculiarity which arises from the specific relationship between a concrete shipper and a port actor can be modelled by what actually goes into the various fields of the framework. The cases discussed in chapter 5 showed that this could for example include requirements with regard to a specific SCM subsystem (such as ASDA's requirement to quickly respond to retail consumer demands or Tchibo's need for flexible distribution and return flows), or the role of a certain actor with regard to a shippers' SC such as the coordinating role of Grand Couronne logistics platform in Renault's parts/components inventory management/distribution system or CAT's respective role in finished vehicle inventory management/distribution. In conclusion, it is not the framework per se, which is shipper specific and port actor specific, but the actual configuration of the matrix axes in combination with the matrix's case-dependent content. 
This research has some limitations. Most saliently, the comparison and grouping of SCM subsystems does not follow strict methodological conventions but is first and foremost results-oriented. Subsystems are derived from an analytical discussion, not from a meta-analysis of SC reference models. The latter would add clarity and methodological soundness and could be the subject of future research. Given the current state of research in the SCM-port domain, the chosen path still represents a comprehensive and detailed approach to identifying the multiple facets of SCM.

Further research could include the following aspects: First, a multi-case analysis using the framework could empirically explore whether all SCM subsystems, which have been retrieved from theory-led SCM literature are of empirical relevance in the shipper-port actor context. Furthermore, different port systems can be compared to explore whether different seaports follow different SC strategies or attract specific groups of shippers. Additional research using the framework could explore whether patterns of strategic port choices exist with regard to shippers' SCM strategies.

\section{References}

Analytiqa. 2007. Portcentric Logistics. The Supply Chain of the Future. 2007. Welwyn Garden City. 8 p.

ASDA. 2012. Port-Centric Logistics - Our Experience. Presentation. 14 p. Available from Internet: http://www.modeshiftcentre.org.uk/export/shared/downloads/modeshiftcentre/ sea/Asda_-_Port-Centric_Logistics.ppt

Beresford, A. K. C.; Woo, S.-H; Pettit, S. J. 2011. Improving port performance: from serving ships to adding value in supply chains, in Hall, P.; McCalla, R. J.; Comtois, C.; Slack, B. (Eds.). Integrating Seaports and Trade Corridors, 137-154.

Bichou, K.; Gray, R. 2005a. A critical review of conventional terminology for classifying seaports, Transportation Research Part A: Policy and Practice 39(1): 75-92. http://dx.doi.org/10.1016/j.tra.2004.11.003

Bichou, K.; Gray, R. 2005b. A logistics and supply chain approach to seaport efficiency - an inquiry based on action research methodology, in Kotzab, H.; Seuring, S.; Müller, M.; Reiner, G. (Eds.). Research Methodologies in Supply Chain Management, 413-428.

http://dx.doi.org/10.1007/3-7908-1636-1_27

Bichou, K.; Gray, R. 2004. A logistics and supply chain management approach to port performance measurement, Maritime Policy \& Management 31(1): 47-67. http://dx.doi.org/10.1080/0308883032000174454

BLG Logistics. 2011. The High Bay Warehouse in Bremen. 6 p. Available from Internet: http://www.blg.de/fileadmin/ user_upload/Downloads/Service/BLG-Hochregallager_11_07_en.pdf

Bolstorff, P.; Rosenbaum, R. 2007. Supply Chain Excellence: A Handbook for Dramatic Improvement Using the SCOR Model. 2nd edition. AMACOM. 285 p.

Bowersox, D. J.; Closs, D. J.; Cooper, M. B. 2007. Supply Chain Logistics Management. 2nd edition. McGraw-Hill. 410 p.

Bowersox, D. J.; Closs, D. J.; Cooper, M. B. 2002. Supply Chain Logistics Management. McGraw-Hill. 656 p.

Bowersox, D. J.; Closs, D. J.; Stank, T. P. 1999. 21st Century Logistics: Making Supply Chain Integration a Reality. Council of Supply Chain Management Professionals. 264 p.
Burgess, K.; Singh, P. J.; Koroglu, R. 2006. Supply chain management: a structured literature review and implications for future research, International Journal of Operations \& Production Management 26(7): 703-729. http://dx.doi.org/10.1108/01443570610672202

Carbone, V.; De Martino, M. 2003a. The changing role of ports in supply-chain management: an empirical analysis, Maritime Policy \& Management 30(4): 305-320. http://dx.doi.org/10.1080/0308883032000145618

Carbone, V.; De Martino, M. 2003b. The Integration of Port Operators in the Automotive Supply Chain: The Port of Le Havre and Renault. Presentation. Institut National de Recherche sur les Transports et leur Sécurité (INRETS). Available from Internet: http://www.inrets.fr/fileadmin/ur/ splott/Evenements/EMAR/Presentations/Presentation Carbone_Martino.pdf

Cooper, M. C.; Lambert, D. M.; Pagh, J. D. 1997. Supply chain management: more than a new name for logistics, The International Journal of Logistics Management 8(1): 1-14. http://dx.doi.org/10.1108/09574099710805556

Corsten, H.; Gössinger, R. 2007. Einführung in das Supply Chain Management. Oldenbourg Wissenschaftsverlag. 383 S. (in German).

CSCMP. 2012. CSCMP Supply Chain Management. Council of Supply Chain Management Professionals (CSCMP). Available from Internet: http://cscmp.org/aboutcscmp/definitions.asp

Croxton, K. L.; García-Dastugue, S. J.; Lambert, D. M.; Rogers, D. S. 2001. The supply chain management processes, The International Journal of Logistics Management 12(2): 13-36. http://dx.doi.org/10.1108/09574090110806271

ESC. 2013. What is a Shipper? European Shippers' Council (ESC). Available from Internet: http://www.europeanshippers.eu/top-1/what-is-a-shipper/\#more-2985

Giannakis, M.; Croom, S. R. 2004. Toward the development of a supply chain management paradigm: a conceptual framework, Journal of Supply Chain Management 40(1): 27-37. http://dx.doi.org/10.1111/j.1745-493X.2004.tb00167.x

Hall, P. V. 2004. "We'd have to sink the ships": impact studies and the 2002 West Coast port lockout, Economic Development Quarterly 18(4): 354-367. http://dx.doi.org/10.1177/0891242404269500

Heaver, T. D. 2011. Coordination in multi-actor logistics operations: challenges at the port interface, in Hall, P.; McCalla, R. J.; Comtois, C.; Slack, B. (Eds.). Integrating Seaports and Trade Corridors, 155-170.

Heaver, T. D. 2002. The evolving roles of shipping lines in international logistics, International Journal of Maritime Economics 4(3): 210-230. http://dx.doi.org/10.1057/palgrave.ijme.9100042

Heaver, T.; Meersman, H.; Moglia, F.; Van de Voorde, E. 2000. Do mergers and alliances influence European shipping and port competition?, Maritime Policy \& Management 27(4): 363-373. http://dx.doi.org/10.1080/030888300416559

Hertel, J.; Zentes, J.; Schramm-Klein, H. 2011. Supply-Chain-Management und Warenwirtschaftssysteme im Handel. 2nd edition. Springer. 442 S. (in German).

Herz, N.; Flämig, H. 2012. Integrating supply chain management strategies in port logistics: defining requirements for port actors, in Proceedings of 9th International Meetings on Logistics Research. 15-17 August 2012, Montreàl, Canada. Association Internationale de Recherche en Logistique.

Herz, N.; Flämig, H.; Hall, P. V.; Heaver, T. D. 2013. Explaining collaboration between shippers and other actors of the 
maritime container logistics chain: an example from Vancouver, in Proceedings of IAME 2013 Annual Conference, 3-5 July 2013, Marseille, France. International Association of Maritime Economists.

Heusler, K. F. 2004. Implementierung von Supply Chain Management: Kompetenzorientierte Analyse aus der Perspektive eines Netzwerkakteurs. Deutscher Universitätsverlag. 439 S. (in German).

Horch, N. 2009. Management Control of Global Supply Chains. 1st edition. Josef Eul Verlag GmbH. 376 p.

Jacobs, W.; Hall, P. V. 2007. What conditions supply chain strategies of ports? The case of Dubai, GeoJournal 68(4): 327-342. http://dx.doi.org/10.1007/s10708-007-9092-x

Lambert, D. M. 2008. Supply Chain Management: Processes, Partnerships, Performance. 3rd edition. Supply Chain Management Institute. $431 \mathrm{p}$.

Lambert, D. M.; Cooper, M. C. 2000. Issues in supply chain management, Industrial Marketing Management 29(1): 65-83. http://dx.doi.org/10.1016/S0019-8501(99)00113-3

Lambert, D. M.; García-Dastugue, S. J.; Croxton, K. L. 2005. An evaluation of process-oriented supply chain management frameworks, Journal of Business Logistics 26(1): 2551. http://dx.doi.org/10.1002/j.2158-1592.2005.tb00193.x

Mangan, J. 2009. Port-centric Logistics: Opportunities for Ports? Presentation. School of Marine Science and Technology, Newcastle University. 31 p. Available from Internet: http:// logistics.ie/portal/wp-content/uploads/2009/02/port-centric.pdf

Mangan, J.; Lalwani, C.; Fynes, B. 2008. Port-centric logistics, The International Journal of Logistics Management 19(1): 29-41. http://dx.doi.org/10.1108/09574090810872587

Marlow, P. B.; Paixão Casaca, A. C. 2003. Measuring lean ports performance, International Journal of Transport Management 1(4): 189-202.

http://dx.doi.org/10.1016/j.ijtm.2003.12.002

Maxingvest AG. 2012. Maxingvest AG - Annual Report 2011. 144 p. Available from Internet: http://www.tchibo-nachhaltigkeit.de/csrweb/servlet/cb/955010/data/-/maxingvestagAnnualReport2011.pdf

Mentzer, J. T.; DeWitt, W.; Keebler, J. S.; Min, S.; Nix, N. W.; Smith, C. D.; Zacharia, Z. G. 2001. Defining supply chain management, Journal of Business Logistics 22(2): 1-25. http://dx.doi.org/10.1002/j.2158-1592.2001.tb00001.x

Notteboom, T. 2006. Fostering seaports - and beyond: challenging the challengers, in Proceedings of ITMMA Maritime and Port Symposium. 25-28 October, 2006, Antwerp, Belgium. Institute of Transport and Maritime Management.

Panayides, P. M. 2006. Maritime logistics and global supply chains: towards a research agenda, Maritime Economics \& Logistics 8(1): 3-18.

http://dx.doi.org/10.1057/palgrave.mel.9100147

Panayides, P. M.; Song, D.-W. 2009. Port integration in global supply chains: measures and implications for maritime logistics, International Journal of Logistics Research and Applications 12(2): 133-145. http://dx.doi.org/10.1080/13675560902749407

PD Ports. 2010. Tees \& Hartlepool Ports Handbook. Land \& Marine Publications Ltd. 74 p. Available from Internet: http://www.pdports.co.uk/Documents/Media\%20Centre/ Brochures/Teesport\%20Handbook\%20final\%202010.pdf

Poluha, R. G. 2010. Anwendung des SCOR-Modells zur Analyse der Supply Chain: Explorative empirische Untersuchung von Unternehmen aus Europa, Nordamerika und Asien. Josef Eul Verlag GmbH. 520 S. (in German).
Poluha, R. G. 2007. Application of the SCOR Model in Supply Chain Management. Cambria Press. 480 p.

Port of Antwerp. 2010. Emphasis on Supply Chain Thinking. Available from Internet: http://annualreport2010.portofantwerp.com/en/page/152/emphasis-on-supply-chainthinking

Robinson, R. 2002. Ports as elements in value-driven chain systems: the new paradigm, Maritime Policy \& Management 29(3): 241-255. http://dx.doi.org/10.1080/03088830210132623

Slack, B.; Comtois, C.; Sletmo, G. 1996. Shipping lines as agents of change in the port industry, Maritime Policy \& Management 23(3): 289-300. http://dx.doi.org/10.1080/03088839600000090

Soni, G.; Kodali, R. 2013. A critical review of supply chain management frameworks: proposed framework, Benchmarking: an International Journal 20(2): 263-298. http://dx.doi.org/10.1108/14635771311307713

Stahlknecht, P.; Hasenkamp, U. 2004. Einführung in die Wirtschaftsinformatik. Springer. 580 S. (in German).

SCC. 2010. Supply Chain Operations Reference (SCOR $\left.{ }^{\circledR}\right)$ Model: Overview -Version 10.0. Supply Chain Council (SCC). 24 p. Available from Internet: http://supply-chain.org/f/ SCOR-Overview-Web.pdf

Stumm, C. 2010. Der Ablader im Seehandelsrecht: Eine rechtsvergleichende Darstellung des deutschen und des amerikanischen Rechts. Lit Verlag. 232 S. (in German).

Talley, W. K. 2009. Port Economics. Routledge. 232 p.

Van der Lugt, L. M.; De Langen, P. W. 2005. The changing role of ports as locations for logistics activities, Journal of International Logistics and Trade 3(2): 59-72.

Wall, G. 2007. Heading for the coast: is port-centric logistics the way forward?, Logistics and Transport Focus 9(8): $42-44$.

Zhou, H.; Benton, W. C.; Schilling, D. A.; Milligan, G. W. 2011. Supply chain integration and the SCOR model, Journal of Business Logistics 32(4): 332-344. http://dx.doi.org/10.1111/j.0000-0000.2011.01029.x 